\title{
The Expression of STAT3, BCL-XL and MMP-2 Proteins in Colon Adenocarcinomas and their Relationship with Prognostic Factors
}

\author{
Kolon Adenokarsinomlarında STAT3, BCL-XL ve MMP-2 Proteinlerinin \\ Salınımının Tanısal Değeri ve Prognostik Faktörler ile İlişkisi
}

\author{
Gökhan ARTAŞ, H. İbrahim ÖZERCAN
}

Departments of Pathology, Firat University Hospital, ELAZIĞ, TURKEY

\begin{abstract}
Objective: Colon adenocarcinomas are the most common malignancy of the gastrointestinal tract. Many factors are described in the prognosis. Herein we aimed to determine the relationship between signal transducer and activator of transcription 3(STAT3), B-cell lymphoma-extra large (Bcl-xL) and matrix metalloproteinase-2 (MMP-2) expression in colon adenocarcinomas and their relationship with prognostic factors.
\end{abstract}

Material and Method: A total of 45 colon adenocarcinomas (15 well, 15 moderately, 15 poorly differentiated) and 15 normal colon mucosa samples were selected randomly. The STAT3, Bcl-xL and MMP-2 immunohistochemicals were applied to the samples.

Results: There was a significant difference between the normal mucosa and carcinoma group regarding the STAT3 staining diffuseness and intensity $(\mathrm{p}<0.05)$, but not for $\mathrm{Bcl}-\mathrm{xL}(\mathrm{p}>0.05)$. The intensity of MMP-2 significantly differed between the normal mucosa and the carcinoma group $(\mathrm{p}<0.05)$. The diffuseness of STAT3 and the intensity of MMP2 showed a significant association with the degree of differentiation $(\mathrm{p}<0.05)$. The intensity and diffuseness of BcL-xL did not show a relationship with the degree of differentiation $(p>0.05)$. Evaluation of the diffuseness and intensity of the three markers with lymph node metastasis and tumor size revealed that only MMP2 diffuseness had a negative correlation with tumor size $(r=-0.318)$.

Conclusion: We observed that $\mathrm{Bcl}-\mathrm{xL}$ does not have a role in the diagnosis of colon adenocarcinomas or the detection of the degree of differentiation, a prognostic factor, but such a relationship was observed for STAT3 and MMP-2.

Key Words: Colonic neoplasms, STAT3 protein, Bcl-xL protein, Matrix Metalloproteinase 2, Prognosis

\section{ÖZ}

Amaç: Kolon adenokarsinomları gastrointestinal sistemin en yaygın malignitesidir. Prognozda önemi olan birçok faktör tanımlanmıştır. Çalışmamızda, kolon adenokarsinomlarında Transkripsiyonun Sinyal Dönüştürücü ve Aktivatörü 3 (STAT3), B Hücreli Lenfoma Oldukça Büyük (Bcl-xL) ve Matrix Metalloproteinaz-2 (MMP-2) proteinlerinin salınımı ve prognostik faktörlerle ilişkisini belirlemeyi amaçladık.

Gereç ve Yöntem: Çalışmamıza rastgele seçilen 45 kolon adenokarsinomu (15 iyi diferansiye, 15 orta derecede diferansiye, 15 az diferansiye) ve 15 normal kolon mukozası örneği alındı. Kesitlere immünohistokimyasal olarak STAT3, Bcl-xL ve MMP-2 uyguland.

Bulgular: STAT3 boyanma şiddeti ve yaygınlığı normal mukoza ve karsinom grubu arasında anlamlı farklılık gösterirken $(\mathrm{p}<0,05) \mathrm{Bcl}-$ xL'de farklılık bulunmadı ( $\mathrm{p}>0,05)$. MMP-2 şiddetinde kontrol grubu ile karsinomlu grup arasinda anlaml farklılı bulundu $(\mathrm{p}<0,05)$. STAT3 yaygınlığı ve MMP2'nin şiddeti ile tümörün diferansiasyon dereceleri arasında anlamlı farklılık bulundu $(\mathrm{p}<0,05)$. Bcl-xL yaygınlık ve şiddeti ile tümörün diferansiasyonu arasındaki ilişki anlamsızdı $(\mathrm{p}>0,05)$. Her üç belirtecin yaygınlığı ve şiddeti ile lenf düğümü metastazı ve tümör çapı arasındaki ilişkide sadece MMP-2 yaygınlığı ile tümör çapı arasında ters korelasyon bulundu $(r=-0,318)$.

Sonuç: Sonuç olarak, kolon adenokarsinomların tanısında ve prognostik faktörlerden olan tümörün diferansiasyon derecelerinin saptanmasında Bcl-xL'nin herhangi bir rolü olmadığı, bununla birlikte STAT3 ve MMP-2'nin belirgin ilişkisi olduğu görüldü.

Anahtar Sözcükler: Kolon tümörleri, STAT3 protein, Bcl-xL protein, Matrix Metalloproteinase 2, Prognoz
(Turk Patoloji Derg 2014, 30:178-183)

Received : 17.03.2014 Accepted : 25.06.2014
Correspondence: Gökhan ARTAŞ

Firat Üniversitesi Hastanesi, Patoloji Anabilim Dalı, ELAZIĞ, TURKEY

E-mail: gartas79@yahoo.com Phone: +90 5057768315 


\section{INTRODUCTION}

Colon adenocarcinomas are the most common malignancy of the gastrointestinal tract and one of the main causes of mortality and morbidity worldwide (1). They make up $9.7 \%$ of all cancer types. They are the fourth most common cancer after lung, prostate and gastric carcinomas in males and the third most common frequency after breast and uterine cervix carcinomas in females (2).

Colorectal carcinomas are most commonly seen between the ages of 60 and 79 years and the incidence increases with age. Although uncommon before the age of 40 years, development is possible due to genetic predisposition and inflammatory bowel disease in this age group (1-4). Several prognostic factors have been defined in colorectal carcinoma and the most important one is the tumor stage. The most widely used and accepted staging system is TNM staging (5).

STAT3 is a member of the STAT family and these proteins are transcription factors serving in the cytoplasm and are significant mediators of growth factors together with the cytokines. Seven types of STAT have been defined in mammals and STAT3 is located in chromosome 17 (6). Current studies show that STAT proteins play an important role in cell proliferation, differentiation and apoptosis (79). STAT3 activation has been shown to contribute to the apoptotic process of the ovarian cancer cells by regulating the release of Bcl-xL protein (10). Activated STAT3 has been found to affect the invasion of melanoma cells by regulating MMP-2 gene transcription (11).

$\mathrm{Bcl}-\mathrm{xL}$ is a member of the Bcl-2 family and was first defined by Boise et al. It regulates the electrical and osmotic balance of mitochondria against various stimuli as a mitochondrial membrane protein and extends the life of the cells (12). This protein is known to have a significant role in the regulation of apoptosis (13).

MMP-2 is a zinc-dependent endopeptidase and can reduce many components of the basal membrane and extracellular matrix (14). MMP-2 is a type of IV collagenase $72 \mathrm{kDa}$ in weight and is also known as Gelatinase $(15,16)$. The MMP family can reduce the extracellular matrix and consists of highly conserved enzymes (17). More than 24 members have been defined so far according to zinc ion activity, pro domain unit, specific amino acid sequence and inhibitors (18).

Our aim in this study was to determine the immunoactivity of STAT3, Bcl-xL and MMP-2 and to investigate their relationship with the prognostic factors.

\section{MATERIAL and METHOD}

A total of 15 normal colon mucosa and 45 colon adenocarcinoma (15 well differentiated (WD), 15 moderately differentiated (MD), 15 poorly differentiated (PD)) cases diagnosed at the pathology laboratory of our hospital between 2000 and 2012 were evaluated and included in the study after the approval of the ethics committee was obtained.

Archive preparations of the cases were re-evaluated under the light microscope and once the diagnoses were verified, profiles 4 micrometer in thickness were taken from the paraffin blocks for immunohistochemical (IHC) investigation. The staining procedure was performed with the staining device (Ventana Medical System, SN: 712299, REF: 750-700, Arizona, USA). Slides stained with antibodies were evaluated under the light microscope. Cytoplasmic staining was accepted as positive for all three stains.

The percentage of the positive-stained areas and the intensity of the staining were recorded in all cases. Accordingly, cytoplasmic staining in more than $70 \%$ of the cells was considered $3(+), 41 \%$ to $70 \%$ was $2(+), 10 \%$ to $40 \%$ was $1(+)$, and less than $10 \%$ or no staining was negative $(0)$. The staining intensity was scored from 1 to 3 as weak (1+), moderate $(2+)$ and intense ( $3+)$. The data were expressed as mean and standard deviation. The Chi-square test was used for categorical data and Spearman Correlation analysis for correlation analysis to analyze the differences between the control and the patient group.

\section{RESULTS}

Of the 60 cases included in the study, 12 of the 15 cases in the control group were males $(80 \%)$ and 3 were females (20\%) while 33 of the 45 cases diagnosed with carcinoma were males $(73.3 \%)$ and 12 were females $(26.7 \%)$. The mean age was $57.80 \pm 13.40$ years in the control group, $54.33 \pm 13.56$ years in well-differentiated carcinomas, $63.33 \pm 17.07$ years in moderately differentiated carcinomas and $63.73 \pm 11.08$ years in poorly differentiated carcinomas. No statistically significant difference was observed between the groups in terms of age ( $>0.05$ ). The mean tumor diameter was $5.14 \mathrm{~cm}$ in the WD, $5.37 \mathrm{~cm}$ in the $\mathrm{MD}$ and $7.63 \mathrm{~cm}$ in the PD group. Lymph node metastasis was present in 5 of 15 cases in the WD and MD groups and in 11 of 15 cases in the PD group.

We first evaluated the STAT3, Bcl-xL and MMP-2 diffuseness and intensity in the control group and carcinoma groups in the study. There was a significant difference between the control group and carcinoma regarding the STAT3 diffuseness and intensity. The difference was especially marked for STAT3 diffuseness in the carcinoma group. 
No difference was found between the control group and carcinoma groups in terms of the diffuseness and intensity of Bcl-xL staining $(\mathrm{p}>0.05)$. No difference was found between the control group and the carcinoma groups regarding MMP-2 diffuseness ( $p>0.05)$. A significant difference was found between the control group and the carcinoma group regarding MMP-2 intensity $(\mathrm{p}<0.05)$ (Figure $1 \mathrm{~A}-\mathrm{F}$ ) (Table I).

A significant relationship was found between STAT3 diffuseness and tumor differentiation $(p<0.05)$. The degree of diffuseness in well and moderately differentiated carcinomas was less marked than the poorly differentiated carcinomas. No significant difference was found between the WD, MD and PD groups in terms of STAT 3 intensity, and $\mathrm{Bcl}-\mathrm{xL}$ diffuseness and intensity $(\mathrm{p}>0.05)$. MMP-2 intensity showed a statistically significant difference between the $\mathrm{WD}, \mathrm{MD}$ and PD groups $(\mathrm{p}<0.05)$. The staining intensity in poorly differentiated carcinomas were more prominent than in the well and moderately differentiated carcinomas (Table I).
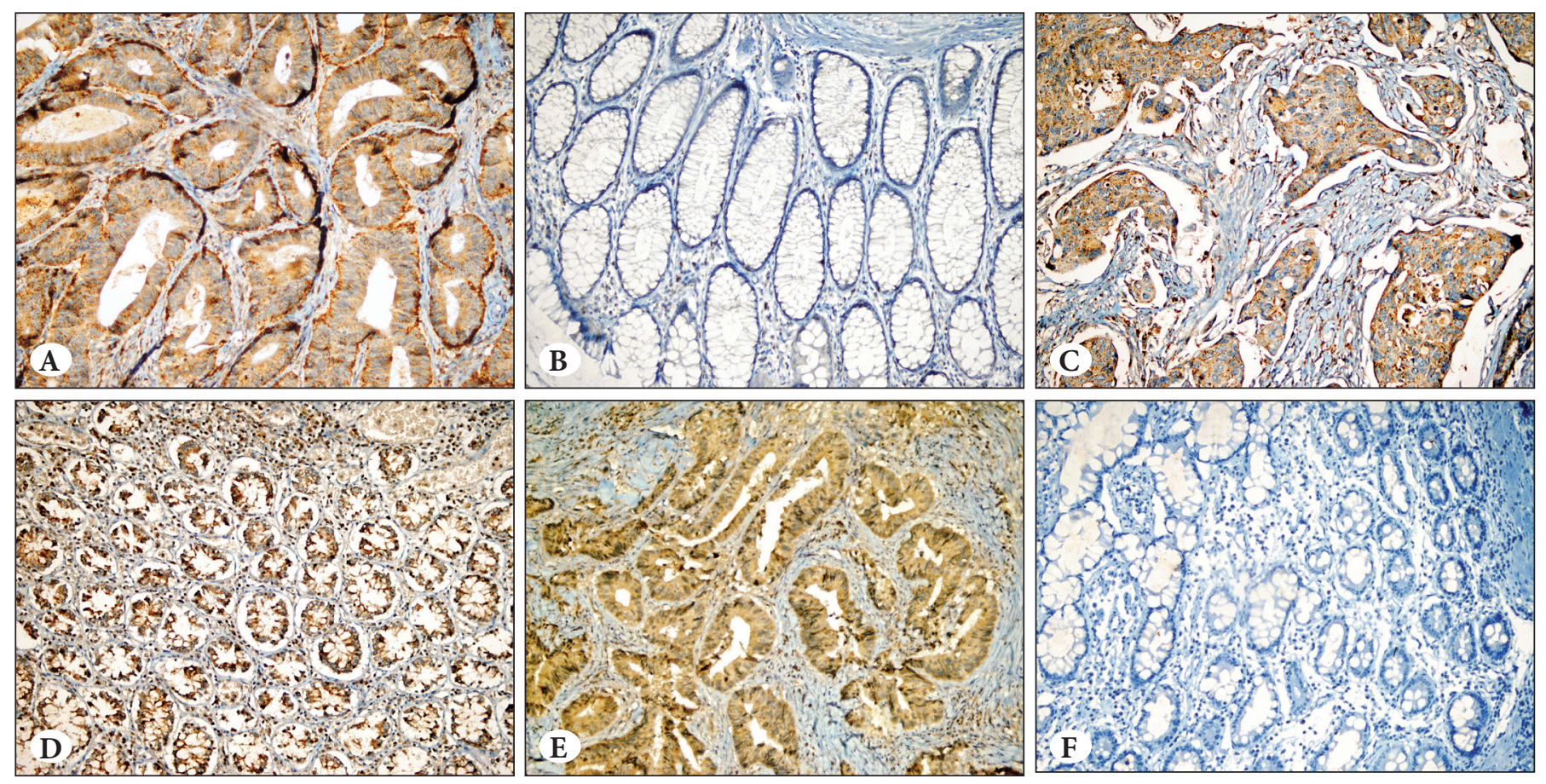

Figure 1: A) 3+ cytoplasmic staining with STAT3 in well-differentiated adenocarcinoma (Immunoperoxidase, x200). B) No STAT3 staining was seen in the control group (Immunoperoxidase, x200). C) 3+ cytoplasmic staining with Bcl-xL in poorly differentiated adenocarcinoma (Immunoperoxidase, x200). D) 3+ cytoplasmic staining with Bcl-xL in the control group (Immunoperoxidase, x200). E) 1+ cytoplasmic staining in MMP-2 in moderately differentiated adenocarcinoma (Immunoperoxidase, x200). F) No MMP-2 staining was seen in the control (Immunoperoxidase, x200).

Table I: The distribution of diffuseness and Intensity of STAT3, BCL-XL and MMP-2 between the control group and degrees of differentiation

\begin{tabular}{|c|c|c|c|c|c|c|c|c|c|c|c|c|c|c|c|c|c|}
\hline \multirow{3}{*}{\multicolumn{2}{|c|}{ Immunohistochemical markers }} & \multirow{2}{*}{\multicolumn{4}{|c|}{ Normal mucosa $(\mathrm{n}=15)$}} & \multicolumn{12}{|c|}{ Carcinoma group $(n=45)$} \\
\hline & & & & & & \multicolumn{4}{|c|}{ WD $(n=15)$} & \multicolumn{4}{|c|}{$\operatorname{MD}(n=15)$} & \multicolumn{4}{|c|}{ PD $(n=15)$} \\
\hline & & $\mathbf{0}$ & $1+$ & $2+$ & $3+$ & $\mathbf{0}$ & $1+$ & $2+$ & $3+$ & $\mathbf{0}$ & $1+$ & $2+$ & $3+$ & $\mathbf{0}$ & $1+$ & $2+$ & $3+$ \\
\hline \multirow{2}{*}{ STAT3 } & Diffuseness & 5 & 3 & 4 & 3 & 0 & 0 & 0 & 15 & 0 & 0 & 0 & 15 & 0 & 2 & 3 & 10 \\
\hline & Intensity & 5 & 7 & 3 & 0 & 0 & 5 & 5 & 5 & 0 & 6 & 7 & 2 & 0 & 8 & 5 & 2 \\
\hline \multirow{2}{*}{ BCL-XL } & Diffuseness & 1 & 2 & 0 & 12 & 0 & 0 & 0 & 15 & 0 & 0 & 0 & 15 & 0 & 2 & 0 & 13 \\
\hline & Intensity & 1 & 4 & 7 & 3 & 0 & 3 & 7 & 5 & 0 & 7 & 8 & 0 & 0 & 7 & 6 & 2 \\
\hline \multirow{2}{*}{ MMP-2 } & Diffuseness & 2 & 3 & 4 & 6 & 0 & 0 & 5 & 10 & 0 & 4 & 3 & 8 & 0 & 2 & 7 & 6 \\
\hline & Intensity & 2 & 7 & 5 & 1 & 0 & 10 & 5 & 0 & 0 & 13 & 2 & 0 & 0 & 13 & 0 & 2 \\
\hline
\end{tabular}

WD: Well differentiated, MD: Moderately differentiated, PD: Poorly differentiated 
No significant relationship was observed between STAT3 and $\mathrm{Bcl}-\mathrm{xL}$ diffuseness and intensity and the tumor diameter $(p>0.05)$. A reverse correlation was found between the MMP-2 diffuseness and tumor diameter $(\mathrm{p}<0.05 ; \mathrm{r}=-0.318)$ (Figure 2). No significant relationship was seen between MMP-2 intensity and tumor diameter ( $\mathrm{p}>0.05)$.

No significant relationship was found between STAT3, Bcl$\mathrm{xL}$ and MMP-2 diffuseness and intensity and lymph node metastasis $(\mathrm{p}>0.05)$

\section{DISCUSSION}

Colon adenocarcinomas are the most common malignancy of the gastrointestinal tract and one of the main causes of mortality and morbidity worldwide (1). According to the 2006 data in Turkey, they are the fourth most common cancer type in males (19).

The diagnostic value of STAT3, Bcl-xL and MMP-2 that are thought to play a role in various stages of cell growth, differentiation, proliferation and angiogenesis and also tumor invasion and metastasis, and their relationship with the prognostic factors of tumor differentiation, tumor diameter and lymph node metastasis in colon adenocarcinomas were investigated in this study.

STAT3 is a transcription factor that is activated by many cytokines and growth factor and plays a key role in cell life, proliferation and differentiation $(6,8)$. It is a member of the JAK/ STAT signaling pathway. The STAT3 protein has been found in the breast, head-neck, liver, melanoma, prostate and pancreas cancers and in many malignant tumors such as leukemia. Current studies have demonstrated that the activation of this protein contributes to oncogenesis (6). A limited number of articles on STAT3 and colon adenocarcinoma are available in the literature. STAT3 was seen in $90 \%$ of adenomas and $97 \%$ of carcinomas in the study by Lee et al. (20) conducted on 20 adenoma and 39 carcinoma cases. While they found no relationship between STAT3 presence and lymph node metastasis and stage, a significant relationship was found between histological grade, distant metastasis and tumor diameter in the same study. We found that the STAT3 diffuseness and intensity showed a significant difference between the control group and the carcinoma groups in our study $(\mathrm{p}<0.001)$. There was $3+$ diffuseness of staining in 40 (88.9\%) of the 45 carcinoma cases. The carcinoma group showed intense staining.

While 3+ diffuseness of staining was seen all WD and MD cases, it was present in only $66.7 \%$ of the PD cases when an evaluation was made according to degree of differentiation. The staining diffuseness in WE and MD cases was significantly different than in PD cases $(\mathrm{p}<0.05)$. However, no significant relationship was found between the degree of tumor differentiation and staining intensity $(\mathrm{p}>0.05)$.

Ma et al. (21) evaluated 45 colorectal carcinomas and reported that the highly activated STAT3 level showed a significant correlation with lymph node metastasis and the stage. Kusaba et al. (22) reported that STAT3 presence was correlated with tumor invasion depth, lymphatic invasion, Dukes stage and post-operative survival, but did not show a relationship with lymph node metastasis and the differentiation of the tumor. STAT3 diffuseness and intensity showed no significant relationship with tumor diameter or lymph node metastasis in our study $(\mathrm{p}>0.05)$. We found $3+$ diffuseness of staining in 18 (85.7\%) of 21 cases with positive lymph node metastasis and in 22 (91.7\%) of 24 cases without metastasis.

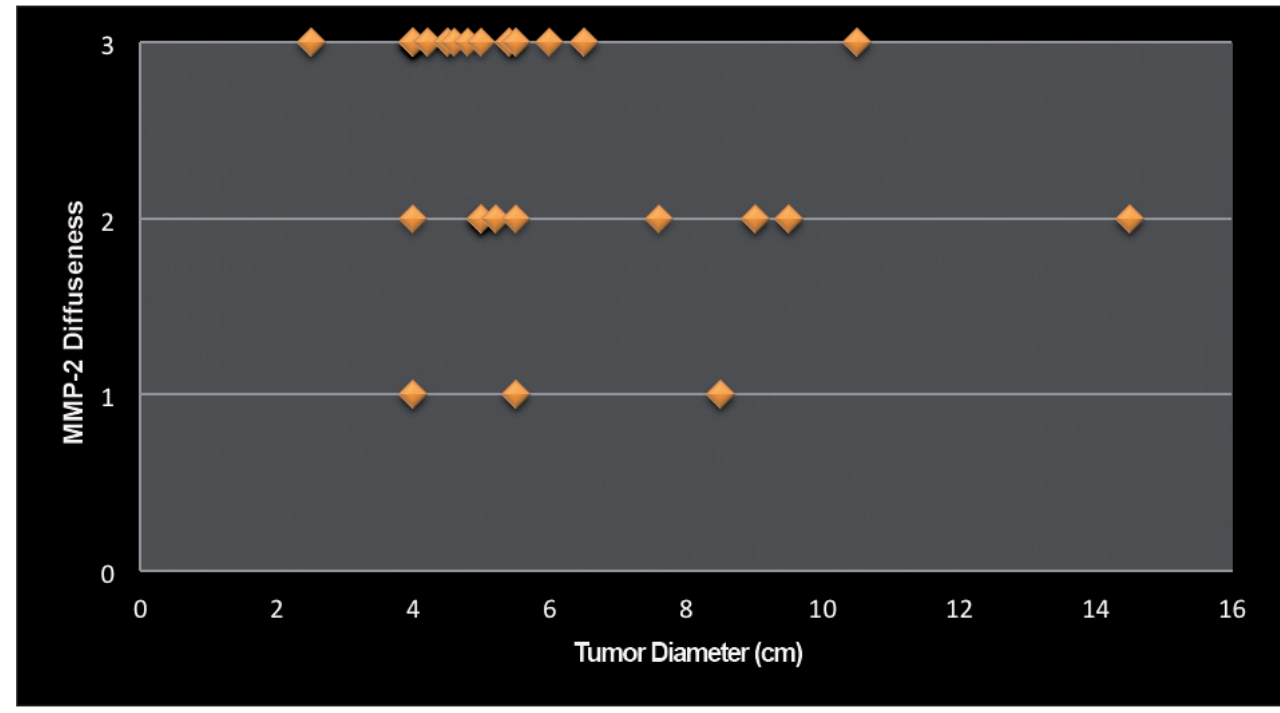

Figure 2: Relationship between MMP-2 diffuseness and tumor diameter. 
Bcl-2 and Bcl-xL are important antiapoptotic factors and this effect stems from their ability to manage antioxidant factors (23). Bcl-xL also neutralizes p53 activity (24). $\mathrm{Bcl}-\mathrm{xL}$ has been reported to be present in high amounts in various tumor types such as colon carcinomas, lung adenocarcinomas, breast carcinomas, squamous cell carcinoma of the lung, ovary carcinomas, bladder carcinomas, ductal adenocarcinomas of the pancreas, and prostate carcinomas (25-32). Lee et al. (20) reported that the Bcl-xL intensity in colorectal carcinomas is higher than in adenomas and the secretion is higher in WD and MD cases than PD cases. We found no significant difference between the control group and the groups with carcinoma and between the various degrees of differentiation of the tumor in terms of diffuseness and intensity of Bcl-xL in our study ( $>0.05$ ). Zhang et al. (33) reported that Bcl-xL level showed a significant relationship with lymph node metastasis, Dukes stage and pathological degree in colorectal carcinomas in their study. No significant relationship was found between Bcl-xL diffuseness and intensity and the tumor diameter and lymph node metastasis in our study $(\mathrm{p}>0.05)$. The diffuseness and intensity of $\mathrm{Bcl}-\mathrm{xL}$ was different between the tumor diameters but there was no statistically significant correlation ( $\mathrm{p}>0.05)$.

MMP-2 has been reported to be present at high levels in tumors of various organs such as the colon, brain, lung, breast, ovary, pancreas and lung $(15,34)$. Poulsom et al. (15) reported that the MMP-2 protein is found in high levels in colorectal carcinomas. They emphasized that MMP-2 staining was present in desmoplastic stroma adjacent to the tumor together with staining fibroblasts, macrophages and endothelial cells within the stroma. Tomita et al. (35) reported that normal mucosa and hyperplastic polyps showed weak staining while adenomas showed stronger staining and in situ carcinomas had significantly stronger staining. We found $3+$ diffuseness in $24(53.3 \%)$ of 45 cases with carcinoma and in $6(40 \%)$ of 15 cases in the control group with no statistically significant difference between the groups ( $>00.05)$. A significant difference was found between the control group and the carcinoma group $(\mathrm{p}<0.05)$. Similar to the two previous studies, we found staining in the desmoplastic stroma and in the endothelial cells and fibroblasts within the stroma.

Shin et al. (36) reported that MMP-2 release level showed correlation with the differentiation of the tumor, lymphatic invasion and Dukes stage in colon carcinomas in their study. Lee et al. (20) reported that MMP-2 levels in colon adenocarcinomas are higher than in adenomas but no significant association was present between the lymph node metastasis and the pathological stage. No significant difference was seen between MMP-2 intensity and the differentiation of the tumor in our study $(\mathrm{p}>0.05)$. However, the difference between MMP-2 intensity and the differentiation of the tumor was statistically significant $(\mathrm{p}<0.05)$. The staining intensity in poorly differentiated carcinomas was more prominent than in the well and moderately differentiated carcinomas. Regarding the prognostic factors, a reverse correlation was observed between the tumor diameter and MMP-2 diffuseness and the result was statistically significant $(\mathrm{P}<0.05 ; \mathrm{r}=-0.318)$. However, no significant relationship was seen between the staining intensity and the tumor diameter $(\mathrm{p}<0.05)$. We also found no significant relationship between lymph node metastasis and MMP-2 diffuseness and intensity $(\mathrm{p}<0.05)$.

In conclusion, Bcl-xL has no role in the diagnosis of adenocarcinomas and the determination of the differentiation of the tumor that is one of prognostic factors. STAT3, as known a regulator of transcription at cell proliferation and differentiation, and MMP-2, which serves as a protective gene for cell functions, have a significant relationship. More comprehensive studies are needed in order to fully explain the pathophysiological effects of these two proteins in carcinogenesis.

\section{REFERENCES}

1. Kumar R, Abbas A, DeLancey A, Malone E. Pathologic basis of disease. 8th. ed, Philadelphia: Saunders; 2010. 815-26.

2. Hamilton SR, Bosman FT, Boffetta P, Ilyas M, Morreau H, Nakamura SI. Carcinoma of the colon and rectum. Bosman FT, Carneiro F, Hruban RH, Theise ND. editors. Pathology and genetics of tumors of the digestive system. Lyon: IARC Press; 2010.132-81.

3. Fenoglio-Preiser CM, Noffsinger AE, Stemmermann GN, Lantz PE, Isaacson PG. Epithelial neoplasms of the colon. Gastrointestinal pathology, an atlas and text. 3rd ed. Philadelphia: Lippincott Williams\&Wilkins; 2008. 898-1034.

4. Odze R, Goldblum JR. Epithelial neoplasms of large intestine. Redston M. editor. Surgical pathology of the GI tract, liver, biliary tract and pancreas. 2nd ed. Philadelphia: Saunders Elsevier; 2009. 597-637.

5. Liu C, Crawford JM. Gastrointestinal sistem. Göksel S (çeviren) Kumar V, Fausto N, Abbas A. Hastalığın patolojik temeli. Sav A, Özdamar ŞO. 7inci baskı. Ankara: Güneș Tip Kitabevleri; 2009. 828-70.

6. Huang S. Regulation of metastases by signal transducer and activator of transcription 3 signaling pathway: Clinic implications. Clin Cancer Res. 2007;13:1362-6.

7. Levy DE, Darnell JE Jr. Stats: transcriptional control and biological impact. Nat Rev Mol Cell Biol. 2002;3:651-62. 
8. Mora LB, Buettner R, Seigne J, Diaz J, Ahmad N, Garcia R, Bowman T, Falcone R, Fairclough R, Cantor A, Muro-Cacho C, Livingston S, Karras J, Pow-Sang J, Jove R. Constitutive activation of Stat3 in human prostate tumors and cell lines: Direct inhibition of Stat3 signaling induces apoptosis of prostate cancer cells. Cancer Res. 2002;62:6659-66.

9. Smithgall TE, Briggs SD, Schreiner S, Lerner EC, Cheng H, Wilson MB. Control of myeloid differentiation and survival by Stats. Oncogene. 2000;19:2612-8.

10. Huang M, Page C, Reynolds RK, Lin J. Constitutive activation of stat 3 oncogene product in human ovarian carcinoma cells. Gynecol Oncol 2000; 79: 67-73.

11. Xie TX, Huang FJ, Aldape KD, Kang SH, Liu M, Gershenwald JE, Xie K, Sawaya R, Huang S. Activation of stat3 in human melanoma promotes brain metastasis. Cancer Res. 2006;66:318896.

12. Boise LH, González-García M, Postema CE, Ding L, Lindsten T, Turka LA, Mao X, Nuñez G, Thompson CB. bcl-x, a bcl-2-related gene that functions as a dominant regulator of apoptotic cell death. Cell. 1993;74:597-608.

13. Tsujimoto Y, Shimizu S. Bcl-2 family: Life-or-death switch. FEBS Lett. 2000;466:6-10.

14. Lynch CC, Matrisian LM. Matrix metalloproteinases in tumorhost cell communication. Differentiation. 2002;70:561-73.

15. Poulsom R, Pignatelli M, Stetler- Stevenson WG, Liotta LA, Wright PA, Jeffrey RE, Longcroft JM, Rogers L, Stamp GW. Stromal expression of $72 \mathrm{kda}$ type IV collagenase (MMP-2) and TIMP-2 mRNAs in colorectal neoplasia. Am J Pathol. 1992;141:389-96.

16. Zucker S, Vacirca J. Role of matrix metalloproteinases (MMPs) in colorectal cancer. Cancer Metastasis Rev. 2004;23:101-17.

17. Brinckerhoff CE, Matrisian LM. Matrix metalloproteinases: A tail of a frog that became a prince. Nat Rev Mol Cell Biol. 2002;3:20714.

18. Woessner JF, Nagase H. Matrix Metalloproteinases and TIMPs. New York: Oxford University Press Inc; 2000. 112-43

19. Ilgun AS, Yildirim N, Sit M, Oner OZ, Gedik ML, Gonullu D, Koksoy FN. Relationship of lymph node ratio, standart prognostic factors and survival in patients with colorectal cancer. JAREM. 2013;3:14-8.

20. Lee SW, Ahn YY, Kim YS, Kang SB, Nam SW, Lee DS, Jeong HY, Kim JM. The Immunohistochemical Expression of STAT3, Bcl$\mathrm{xL}$, and MMP-2 Proteins in colon adenoma and adenocarcinoma. Gut Liver. 2012;6:45-51.

21. Ma XT, Wang S, Ye YJ, Du RY, Cui ZR, Somsouk M. Constitutive activation of Stat3 signaling pathway in human colorectal carcinoma. World J Gastroenterol. 2004;10:1569-73.

22. Kusaba T, Nakayama T, Yamazumi K, Yakata Y, Yoshizaki A, Inoue K, Nagayasu T, Sekine I. Activation of STAT3 is a marker of poor prognosis in human colorectal cancer. Oncol Rep. 2006;15:144551.

23. Hockenbery DM, Oltvai ZN, Yin XM, Milliman CL, Korsmeyer SJ. Bcl-2 functions in an antioxidant pathway to prevent apoptosis. Cell. 1993;75:241-51.
24. Chipuk JE, Bouchier-Hayes L, Kuwana T, Newmeyer DD, Green DR. PUMA couples the nuclear and cytoplasmic proapoptotic function of p53. Science. 2005;309:1732-5.

25. Bose P, Klimowicz AC, Kornaga E, Petrillo SK, Matthews TW, Chandarana S, Magliocco AM, Brockton NT, Dort JC. Bax expression measured by AQUAnalysis is an independent prognostic marker in oral squamous cell carcinoma. BMC Cancer. 2012;12:332-44.

26. Lin HX, Qiu HJ, Zeng F, Rao HL, Yang GF, Kung HF, Zhu XF, Zeng YX, Cai MY, Xie D. Decreased expression of Beclin 1 correlates closely with $\mathrm{Bcl}-\mathrm{xL}$ expression and poor prognosis of ovarian carcinoma. PLoS One. 2013;8:e60516.

27. Korkolopoulou P, Lazaris ACh, Konstantinidou AE, Kavantzas N, Patsouris E, Christodoulou P, Thomas-Tsagli E, Davaris P. Differential expression of bcl-2 family proteins in bladder carcinomas. Relationship with apoptotic rate and survival. Eur Urol. 2002;41:274-83.

28. Hinz S, Trauzold A, Boenicke L, Sandberg C, Beckmann S, Bayer E, Walczak H, Kalthoff H, Ungefroren $\mathrm{H}$. Bcl-XL protects pancreatic adenocarcinoma cells against CD95- and TRAILreceptor-mediated apoptosis. Oncogene. 2000;19:5477-86.

29. Zhou DH, Yang LN, Roder C, Kalthoff H, Trauzold A. TRAILinduced expression of UPA and IL-8 strongly enhanced by overexpression of TRAF2 and Bcl-xL in pancreatic ductal adenocarcinoma cells. Hepatobiliary Pancreat Dis Int. 2013;12:948.

30. Li JY, Li YY, Jin W, Yang Q, Shao ZM, Tian XS. ABT-737 reverses the acquired radioresistance of breast cancer cells by targeting Bcl-2 and Bcl-xL. J Exp Clin Cancer Res. 2012;31:102.

31. Chiyomaru T, Yamamura S, Fukuhara S, Hidaka H, Majid S, Saini S, Arora S, Deng G, Shahryari V, Chang I, Tanaka Y, Tabatabai ZL, Enokida H, Seki N,Nakagawa M, Dahiya R. Genistein upregulates tumor suppressor microRNA-574-3p in prostate cancer. PLoS One. 2013;8:e58929.

32. Li X, Marani M, Mannucci R, Kinsey B, Andriani F, Nicoletti I, Denner L, Marcelli M. Overexpression of BCL-X(L) underlies the molecular basis for resistance to staurosporine-induced apoptosis in PC-3 cells. Cancer Res. 2001;61:1699-706.

33. Zhang YL, Pang LQ, Wu Y, Wang XY, Wang CQ, Fan Y. Significance of $\mathrm{Bcl}-\mathrm{xL}$ in human colon carcinoma. World J Gastroenterol. 2008;14:3069-73.

34. Amălinei C, Căruntu ID, Giuşcă SE, Bălan RA. Matrix metalloproteinases involvement in pathologic conditions. Rom J Morphol Embryol. 2010;51:215-28.

35. Tomita T, Iwata K. Matrix metalloproteinases and tissue inhibitors of metalloproteinases in colonic adenomas- adenocarcinomas. Dis Colon Rectum. 1996;39:1255-64.

36. Shin JE, Jung SA, Kim SE, Joo YH, Shim KN, Kim TH, Yoo K, Moon IH. Expression of MMP-2, HIF-1 alpha and VEGF in colon adenoma and colon cancer. Korean J Gastroenterol 2007;50:9-18. 